\title{
Fitur dan Fasilitas Masjid Berbasis Potensi Fitrah Anak
}

\author{
Salmiah ${ }^{1}$, Ria Wikantari ${ }^{1}$, Afifah Harisah ${ }^{1}$ \\ ${ }^{1}$ Departemen Teknik Arsitektur, Fakultas Teknik, Universitas Hasanuddin \\ Jl. Poros Malino km. 6, Bontomarannu, Kabupaten Gowa, Sulawesi Selatan 92171 \\ *Email: dcore.indonesia@gmail.com
}

DOI: 10.25042/jpe.052019.08

\begin{abstract}
Abstrak
Penelitian ini bertujuan; (1) mengidentifikasi fitur dan fasilitas anak di masjid-masjid di Kota Makassar, (2) mengeksplorasi fitur dan fasilitas masjid berbasis potensi fitrah anak. Penelitian dilakukan di Makassar, menggunakan metode kualitatif dengan menggunakan data kualitatif dan kuantitatif melalui daftar pertanyaan, survey serta wawancara orang tua dan anak pada komunitas parenting dan komunitas da'wah di Makassar. Hasil penelitian menunjukkan bahwa: (1) fitur area salat untuk anak adalah area yang terpisah jika memungkinkan namun tetap terkoneksi dengan area salat utama dengan pengawasan orang tua atau volunteer yang memiliki kedekatan dengan anak. Area salat anak dilengkapi dengan poster (doa anak, bacaan salat, serta adab di masjid), karpet warna-warni, perlengkapan ibadah anak (mukena, peci, alqur'an, sajadah), rak perlengkapan ibadah anak, dan kebutuhan anak yang lain seperti air minum gallon. Sedangkan fasilitas rekreasi anak di masjid-masjid di Kota Makassar belum pernah ditemukan, yang ada adalah masjid sebagai tempat anak-anak belajar AlQur'an. Masjid-masjid di Makassar perlu meningkatkan fasilitas yang ada seperti perpustakaan anak, fasilitas olahraga, tempat wudhu/toilet anak, ruang laktasi, teras yang lapang. (2) Fasilitas masjid berbasis potensi fitrah anak : (0-2 tahun) ruang laktasi, (3-6 tahun) Taman Pendidikan Al-Qur'an, perpustakaan anak, sarana bermain anak, tempat wudhu anak (710) fasilitas olahraga.
\end{abstract}

\begin{abstract}
Fitures and Facilities of Mosque Based on Children's Fitrah. The aims of this study; (1) identifying children's features and facilities in mosques at Makassar City, (2) exploring mosque's features and facilities based on children's fitrah. The study was conducted in Makassar, using qualitative method with qualitative and quantitative data through questionnaires, survey and interview of parents and children in the parenting community and da'wah community in Makassar. The results showed that: (1) the features of the prayer area for children are separate areas if possible but still connected to the main prayer area under the supervision of parents or volunteers who have close relations with children. Children's prayer area is equipped with posters (children's prayers, prayer readings, and manners in the mosque), colorful carpets, children's worship equipment (mukena, cap, quran, prayer mat), shelves for children's worship equipment, and other children's needs such as gallon drinking water. While children's recreational facilities in mosques in Makassar City have never been found, but mosque as a place for children to learn the Qur'an. The mosques in Makassar need to improve existing facilities such as children's libraries, sports facilities, children's toilets/ablution, lactation rooms, spacious terraces. (2) Mosque facilities based on children's fitrah: (0-2 years) lactation room, (3-6 years) Al-Qur'an Education Park, children's library, children's play facilities, children's toilets/ablution (7-10) sports facilities.
\end{abstract}

Kata Kunci: Fitur, fasilitas, fitrah anak, masjid, ramah anak

\section{Pendahuluan}

Menurut Nugroho [1] Tahun 2005 Kementerian Negara Pemberdayaan Perempuan pertama kali memperkenalkan istilah Kota Layak Anak lewat kebijakan Kota Layak Anak yang kemudian berkembang menjadi Kabupaten atau Kota Layak Anak dan disingkat menjadi KLA. Dalam Peraturan Menteri Negara Pemberdayaan Perempuan Republik Indonesia No. 2 Tahun 2009 disebutkan prinsip-prinsip kota layak anak, yaitu non diskriminasi, kepentingan terbaik untuk anak, hak untuk hidup, kelangsungan hidup dan penghargaan terhadap anak.

Makassar sejak 22 September 2014 sudah mendapatkan predikat Kota Layak Anak dengan tujuan untuk membangun inisiatif pemerintah kota agar mengarah pada kebijakan, program, strategi dan kegiatan pembangunan yang mengutamakan hak anak menurut penelitian yang dilakukan oleh Hamudi [2]. Upaya yang dilakukan Kota Makassar untuk memenuhi kriteria sebagai KLA 
adalah menyediakan taman bermain anak yang nyaman di 18 kecamatan, peningkatan jumlah Ruang Terbuka Hijau (RTH). Upaya yang dilakukan Kota Makassar dalam memenuhi kriteria sebagai KLA belum menjadikan masjid sebagai target program ramah anak, padahal masjid tidak kalah pentingnya karena masjid merupakan pusat perawatan dan penumbuhan fitrah anak khususnya fitrah keimanan yang merupakan dasar dari bertumbuhnya fitrah-fitrah anak yang lain. Menurut Suratkom [3] dalam penelitiannya yang berjudul Fitur dan Fasilitas Masjid Ramah Perempuan menyebutkan bahwa hampir seluruh responden mengharapkan adanya fasilitas anak di Masjid.

KLA tidak hanya berlaku di lingkungan keluarga, sekolah, maupun di lingkungan sosial, akan tetapi juga berlaku di lingkungan tempat ibadah, seperti masjid, gereja, pura, vihara, dan lain-lain menurut Ngaderi [4]. Dalam hal ini masjid juga harus menjadi tempat yang berorientasi pada pemenuhan hak anak dalam perawatan dan penumbuhan fitrahnya. Arsitektur masjid harus hadir kembali memenuhi perannya sebagai pusat pembangunan masyarakat islam, sebagai yang dicontohkan Rasulullah SAW dalam membangun peradaban umat islam sebelumnya.

Dalam hadist disebutkan, Abu Daud (no. 495) dan Ahmad (6650) telah meriwayatkan dari Amr bin Syu'aib, dari bapaknya dari kakeknya, dia berkata, "Rasulullah shallallahu alaihi wa sallam bersabda, "Perintahkan anak-anak kalian untuk melakukan shalat saat usia mereka 7 tahun, dan pukullah mereka saat usia 10 tahun. Dan pisahkan tempat tidur mereka." (Dishahihkan oleh AlAlbany dalam Irwa'u Ghalil, no. 247)

Melaksanakan perintah shalat tidak serta merta terjadi begitu saja pada anak. Kebiasaan ini perlu ditumbuhkan sejak dini, sehingga kelak ketika mereka sudah baligh (dewasa) mereka sudah terpaut hatinya dengan masjid, melakukan shalat tanpa diperintahkan karena sudah terbangun kebiasaan sejak usia dini.

Menurut Utaberta [5] warisan dari masjid adalah fungsinya, bukan bentuknya dimasa lampau. Ada 5 program yang harus terakomodasi di Masjid yaitu : program pendidikan, program sosial, program ekonomi, program kesejahteraan masyarakat, program peradilan syari'ah dan berbagai program tambahan seperti program untuk anak-anak.

Berdasar pada Al-Qur'an dan Hadist, Permen PPA Nomor 11 Tahun 2011 serta historiografi fungsi masjid di jaman Rasulullah SAW, seharusnya anak-anak juga menjadi salah satu pelaku utama kegiatan pada bangunan masjid, mereka juga memilki hak dan harus diwadahi aktivitasnya di masjid sebagai tempat merawat, membangkitkan dan menumbuhkan potensi fitrah mereka dengan memenuhi persyaratan kenyamanan, keamanan, keselamatan, dan kesehatan.

Besarnya harapan terhadap anak-anak pembawa misi peradaban ke depannya yang hari ini terdidik dengan baik di lingkungan keluarga, di lingkungan sekolah, dan di lingkungan sosial khususnya di masjid, sangat penting untuk melakukan penelitian awal tentang "Fitur dan Fasilitas Masjid Berbasis Potensi Fitrah Anak".

Tujuan dari penelitian ini untuk mengidentifikasi fitur dan fasilitas untuk kebutuhan anak di Masjid menurut pendapat orang tua da anak, dan untuk mengeksplorasi fitur dan fasilitas masjid yang berorientasi pada perawatan dan penumbuhan fitrah keimanan anak.

\section{Metode Penelitian}

Penelitian ini merupakan jenis penelitian kualitatif dengan metode deskriptif menggunakan paradigma positivisme dengan menggunakan data kualitatif dan kuantitatif. Penelitian ini dilaksanakan di Kota Makassar, akan tetapi tidak fokus pada masjid tertentu sebagai studi kasus karena tidak sesuai dengan tujuan penelitian. Jika fokus pada masjid tertentu sebagai studi kasus, besar kemungkinan pengunjung masjid yang dijadikan informan tidak memahami fitrah anak baik pada tataran konsep maupun aplikasi, sehingga data yang diharapkan tidak sesuai dengan jawaban informan. Subjek dalam penelitian ini yang bertindak sebagai informan adalah para orang tua dalam komunitas parenting. Adapun teknik penentuan informan pada penelitian ini adalah non probability sampling. Teknik non probabilty sampling yang digunakan dalam penentuan informan pada penelitian ini 
adalah teknik purposive sampling. Menurut Sugiono [6] purposive sampling adalah teknik penentuan sample dengan kriteria tertentu. Adapun kriteria-kriteria informan yang ditetapkan antara lain :

- Orang tua muslim/muslimah baik yang berdomisili di Makassar ataupun tidak, namun pernah berkunjung ke masjid-masjid di Makassar.

- Memiliki anak umur 0-10 tahun.

- Menerapkan pendidikan berbasis fitrah pada anak dalam keluarganya.

Jumlah informan yang terjaring melalui link dokumen google sebanyak 58 orang, $40 \%$ informan berjenis kelamin laki-laki dan $60 \%$ berjenis kelamin perempuan dengan rincian sebagai berikut :

- Komunitas HEbAT (Home Education Based on Talent and Akhlaq) sebanyak 30 orang.

- Komunitas IIP (Institut Ibu Profesional) sebanyak 9 orang.

- Komunitas ICATT (Ikatan Cendekiawan Alumni Timur Tengah) sebanyak 8 orang.

- Komunitas lain-lain sebanyak 11 orang.

\section{Hasil dan Pembahasan}

\subsection{Gambaran Khusus Subjek Penelitian}

- Komunitas HEbAT (Home Education based on Akhlaq and Talents)

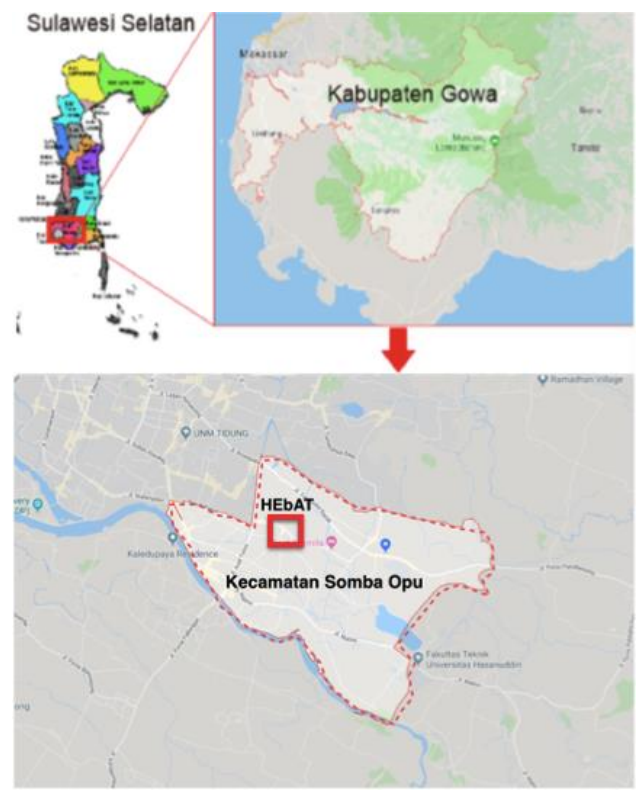

Gambar 1. Peta komunitas HEbAT
Komunitas HEbAT (Home Education based on Akhlaq and Talents) adalah grup diskusi dan berbagi mulai dari konsep pendidikan berbasis akhlaq dan potensi (fitrah), sampai kepada praktik dan menjalin kerjasama jaringan di lapangan. Kekuatan konsep pendidikan berbasis potensi ini ada pada keluarga dan jaringan komunitas, baik untuk pemagangan, keteladanan maupun kemandirian.

Program inti komunitas adalah $\mathrm{CBE}$ (Community Based Education) dan CBB (Community Based Bisnis). Untuk program CBE dibagi berdasarkan usia :

- Kelompok usia di bawah 7 tahun (Belajar bersama alam, mengenal kearifan lokal, dan bahasa ibu).

- Kelompok usia 7-12 tahun (Project Based Learning, ekpedisi, dan riset).

- Kelompok usia 11-17 tahun (Talent Development, pemagangan, sertifikasi dll).

- Program CBE for Parents (Fatherhood Forum, Kuliah FBE, workshop dll).

Sedangkan program $\mathrm{CBB}$ adalah merancang dan membangun unit usaha bersama, sebagai bentuk dukungan operasional untuk kegiatan komunitas. Adapun peran pemberdayaan yang dilakukan adalah bersedianya komunitas HEbAT dalam berperan sebagai influencer/katalisator bagi upaya pemberadaban anak bangsa melalui pendidikan berbasis rumah dengan memfasilitasi elemen berbasis komunitas manapun (Posyandu, PKK dsb.), untuk mengembangkan pendidikan berbasis rumah, baik melalui konsep, program, pembelajaran maupun SDM.

\section{- IIP (Institut Ibu Komunitas Profesional)}

Ibu profesional adalah komunitas para ibu dan calon ibu yang ingin meningkatkan kualitas dirinya dalam menjalankan perannya sebagai seorang perempuan, ibu dan istri yang dibanggakan oleh suami dan anak. Definisi kata profesional berdasarkan Kamus Besar Bahasa Indonesia adalah memerlukan kepandaian khusus untuk menjalankannya. Berdasar dari definisi profesional ini sehingga untuk menjalankan peran sebagai perempuan, ibu dan istri diperlukan sikap profesional (bersungguh-sungguh) dalam belajar 
sehingga mampu memberi manfaat kepada diri, keluarga, dan masyarakat.

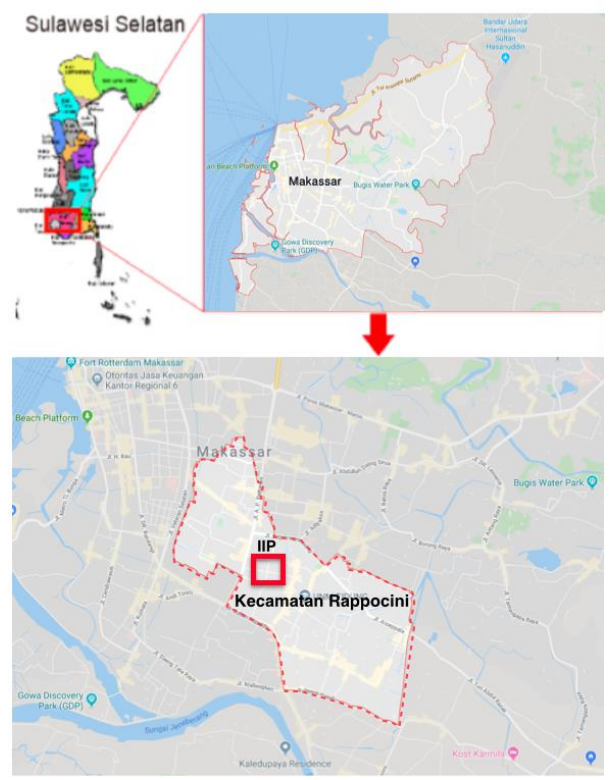

Gambar 2. Peta komunitas IIP

Untuk menuju menjadi ibu profesional tentunya bukan hal yang instan, sehingga diperlukan keputusan untuk memulai langkah pertama. Adapun tahapan-tahapan menuju ibu profesional adalah:

- Bunda sayang

Pada tahapan bunda sayang ini para ibu akan dibekali dengan ilmu-ilmu untuk meningkatkan kualitas ibu dalam mendidik anak-anak, sehingga mampu menjadi guru pertama dan utama bagi anak-anaknya

- Bunda Cekatan

Setelah para ibu berhasil menyelesaikan tahapan bunda sayang maka mereka bisa melanjutkan ke tahapan selanjutnya yaitu bunda cekatan. Pada tahapan bunda cekatan para ibu dibekali dengan ilmu-ilmu untuk meningkatkan kualitas ibu dalam mengelola rumah tangga dan keluarganya sehingga menjadi keluarga yang unggul.

- Bunda Produktif

Ketika para ibu berhasil menerapkan ilmu yang didpatkan pada tahapan bunda sayang dan bunda cekatan maka tahapan selanjutnya adalah bagaimna membekali para ibu untuk meningkatkan rasa percaya dirinya, dengan cara berproses menentukan misi spesifik hidupnya. Dengan menemukan misi specifik hidup maka para ibu mampu produktif dengan bahagia, tanpa harus meninggalkan anak dan keluarganya.

- Bunda Saleh

Pada tahapan ini para bunda dibekali dengan ilmu-ilmu dalam meningkatkan perannya sebagai agen pembawa perubahan di masyarakat, sehingga keberadaannya bermanfaat bagi banyak orang.

- Komunitas ICATT (Ikatan Cendekiawan Alumni Timur Tengah)

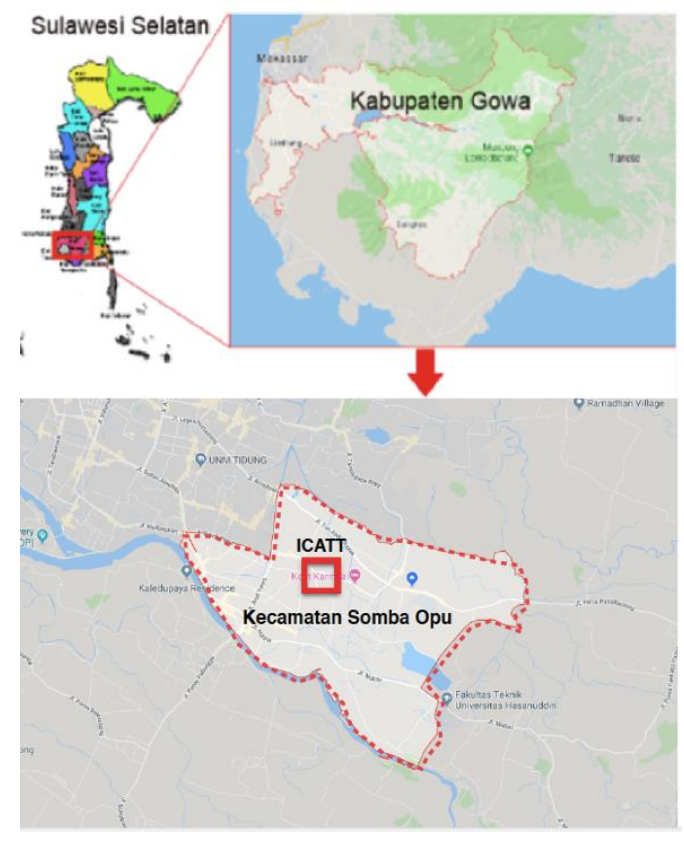

Gambar 3. Peta lokasi sekretariat komunitas ICATT Sulawesi

Ikatan Cendekiawan Alumni Timur Tengah (ICATT) Indonesia adalah wadah yang menghimpun alumni yang pernah belajar di kawasan Timur Tengah yang meliputi Mesir, Sudan, Suriah, Maroko, Tunisia, Arab Saudi dan Pakistan. Jumlah alumni Timur Tengah yang telah kembali ke Indonesia dan berkiprah di dalam berbagai bidang jumlahnya telah mencapai ribuan. Khusus di Sulawesi Selatan jumlahnya sekitar 500-an. Akan tetapi jumlah tersebut belum terdata seluruhnya karena keterbatasan informasi yang detail mengenai keberadaan dan aktifitas para alumni tersebut. 
- Komunitas lain-lain

Informan lainnya dari komunitas rumah inspirasi, rumah main anak dan lainnya belajar parenting dari buku-buku parenting, seminar parenting dan majelis ilmu agama.

\subsection{Survey Lapangan}

Survey lapangan dilakukan pada 3 masjid di Makassar yaitu Masjid Al-Markas Al-Islami Makassar, Masjid Fatimah Bukit Baruga, dan Masjid Baabuttaubah.

- Masjid Al-Markas Al-Islami Makassar

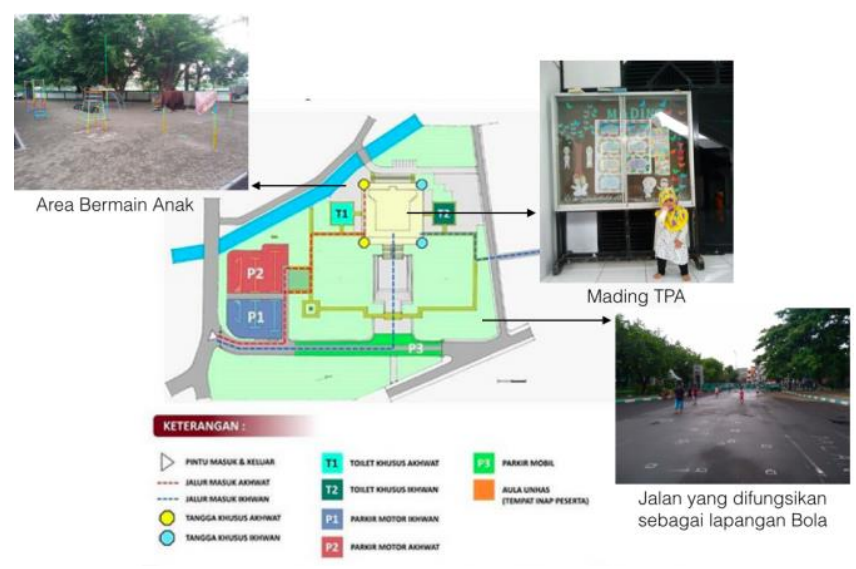

Gambar 4. Site Plan Al-Markas Al-Islami dan Fasilitas Anak

Masjid Al-Markas Al-Islami dibuat untuk melayani masyarakat muslim Kota Makassar. Masjid ini letaknya di Jalan Sunu. Survey dilakukan pada sore hari sebelum salat ashar dan setelah salat ashar. Tampak anak-anak usia 7-10 tahun main bola di area jalan, dan pada saat salat ashar tidak tampak adanya jamaah anak-anak di area ikhwan maupun akhwat. Masjid ini dilengkapi dengan fasilitas anak di lantai 1 yaitu Taman Kanak-Kanak dengan area bermain anak di halaman masjid, sedangkan ruangan kelas berada di masjid lantai 1. Adapun teras masjid yang lapang dimanfaatkan anak-anak mengaji.

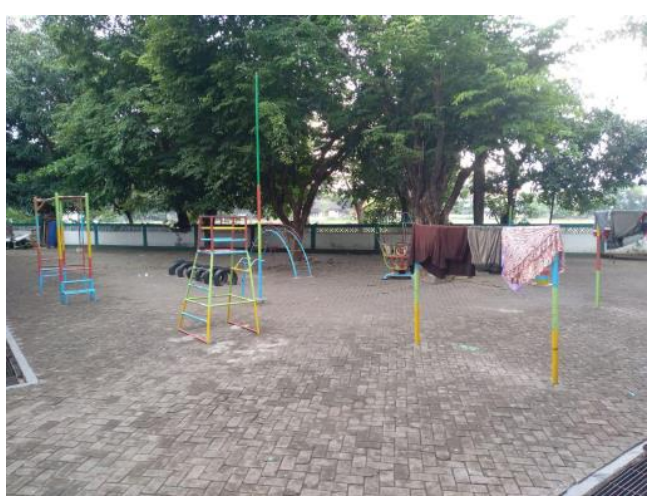

Gambar 5. Area bermain anak
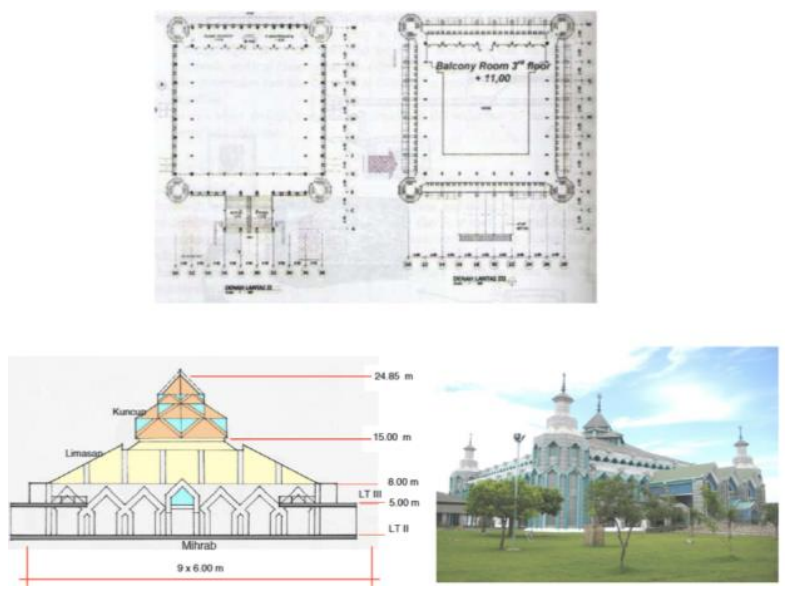

Gambar 6. Denah, tampak dan potongan Masjid AlMarkas Al-Islami dan Fasilitas Anak [7]

- $\quad$ Masjid Fatimah Baruga

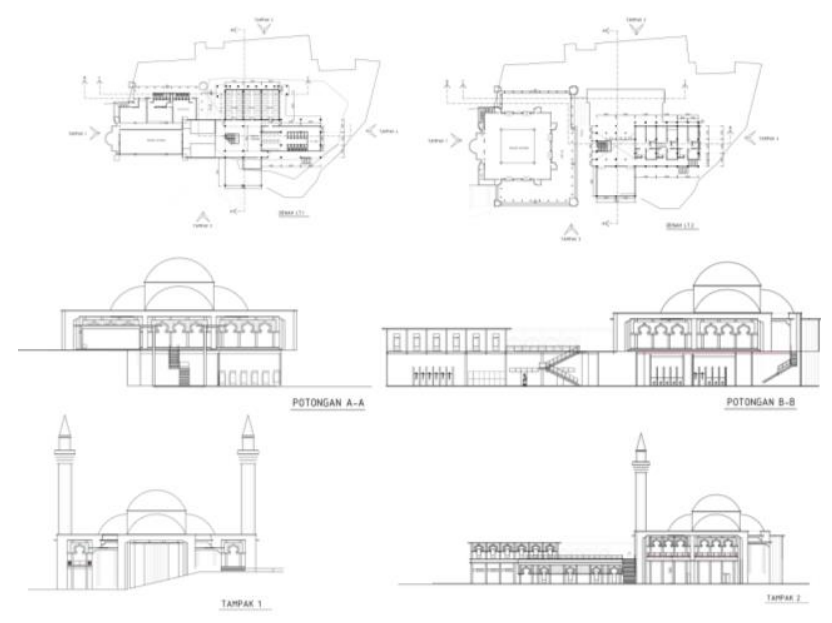

Gambar 7. Denah, tampak dan potongan Masjid Fatimah Baruga 


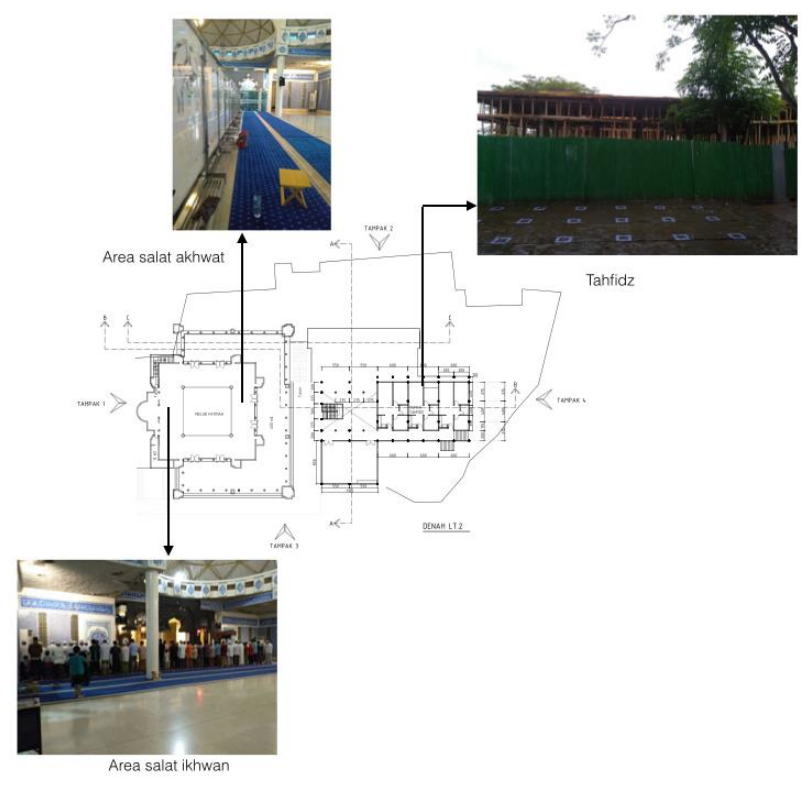

Gambar 8. Ruang salat dan tahfidz Masjid Fatimah Baruga

Masjid Fatimah Baruga terletak di kompleks perumahan Bukit Baruga Antang, Masjid ini dibangun untuk melayani aktivitas ibadah warga, masjid ini dilengkapi dengan fasilitas pesantren tahfidz untuk anak. Adapun fasilitas tahfidz saat ini sementara dibangun di area yang berdampingan dengan area salat di lantai 2 . Survey dilakukan di sore hari menjelang salat magrib.

- Masjid Baabuttaubah
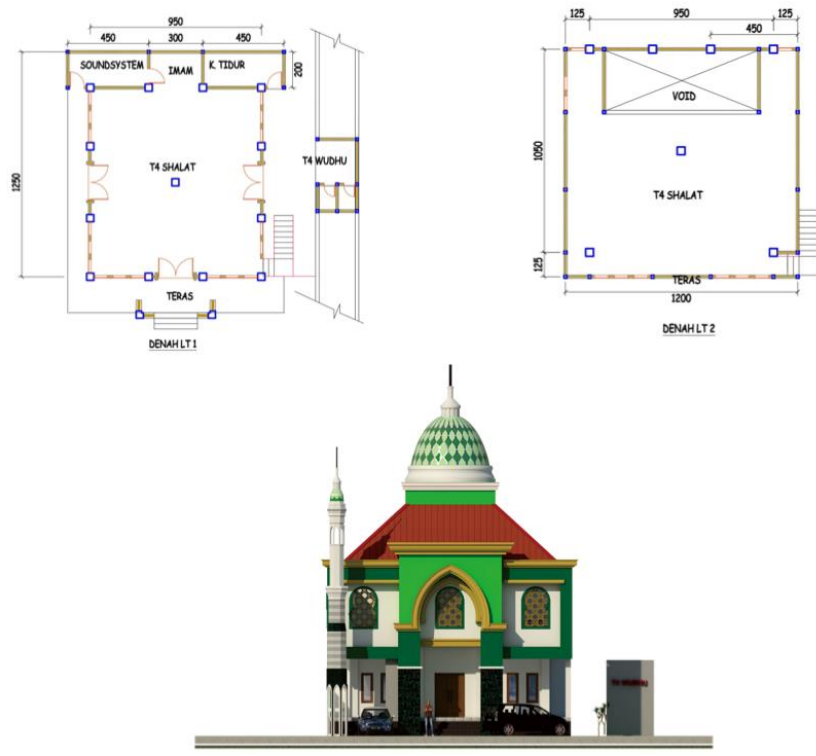

Gambar 9. Ruang salat dan tahfidz Masjid Fatimah Baruga
Sedangkan kondisi masjid Baabuttaubah yang terletak di Kompleks Perumahan Minasaupa, digunakan oleh anak-anak mengaji setiap hari senin sampai hari jumat. Aktivitas mengaji dilakukan di area salat lantai 1.

\subsection{Karakteristik Informan}

- Frekuensi Kunjungan Informan ke Masjid

Membawa anak $=$ Tidak membawa anak Kadang-kadang

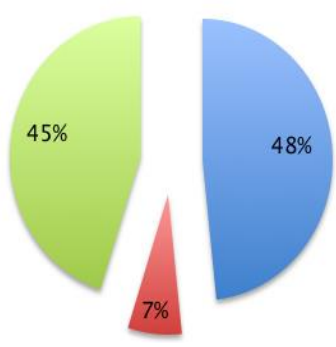

Gambar 10. Frekuensi informan membawa anak ke masjid

- Tujuan Orang Tua Membawa Anak ke Masjid

Tabel 1. Tujuan orang tua membawa anak ke masjid berdasarkan urutan

\begin{tabular}{cl}
\hline No & \multicolumn{1}{c}{ Tujuan Membawa Anak ke Masjid } \\
\hline 1 & Mengenalkan salat jamaah 5 waktu (wajib laki-laki) \\
2 & Mengenalkan dan belajar tata cara ibadah \\
3 & Mengikat hati dan mencintai masjid \\
4 & Mengenalkan masjid sejak usia dini \\
5 & Ikut Ayah/Bunda (tarbiyah/ta'lim) \\
6 & Mengenalkan adab di Masjid \\
7 & Bersosialisasi dengan teman sebaya \\
\hline
\end{tabular}

Tujuan orang tua membawa anak ke masjid berturut-turut berdasarkan urutan jawaban terbanyak adalah mengenalkan salat jamaah wajib 5 waktu untuk laki-laki, akan tetapi untuk anak perempuan salat jamaah bukan hal yang wajib. Tujuan lainnya adalah agar anak-anak mengenal salat dan belajar ibadah dengan cara melihat, mengenal masjid lebih dini sebelum memasuki usia diperintahkan salat yaitu umur 7 tahun agar kelak tumbuh menjadi pribadi yang terikat hatinya dan mencintai masjid. Mereka juga berada di Masjid karena ikut serta Ayah/Bundanya dalam 
aktivitas menuntut ilmu, agar anak bersosialisasi dan mengenalkan adab di Masjid. Semua tujuan ini merupakan upaya-upaya yang dilakukan oleh orang tua sebagai perawatan dan penumbuhan fitrah pada anak-anak mereka.

Hal ini menunjukkan bahwa para orang tua secara sadar akan tujuan kenapa mereka membawa serta anak nya ke masjid. Mereka berharap bahwa masjid adalah rumah kedua yang memberikan kenyamanan dan keamanan bagi anak-anak mereka.

\subsection{Fitur dan Fasilitas Anak pada Masjid-Masjid di Kota Makassar}

\section{- Fitur Area Salat}

Hasil penelitian ini menunjukkan bahwa semua informan belum pernah menemukan perlengkapan ibadah untuk anak pada masjidmasjid di Kota Makassar. Hal ini menandakan bahwa anak belum menjadi subjek dalam mendesain masjid-masjid di Makassar.

Area salat pada masjid adalah sumber utama konflik antara orang dewasa yang ingin beribadah secara khusyu' dengan fitrah anak yang belajar dengan cara bermain. Penggalian pendapat ini bertujuan agar konflik bisa dikurangi atau dihilangkan agar kedua kepentingan bisa terwadahi tanpa harus menjauhkan anak dari masjid terlebih menciderai fitrah mereka lewat verbal ataupun fisik.

Hasil penelitian ini menunjukkan harapan orang tua bahwa keberadaan anak di Masjid perlu diwadahi secara spesifik walaupun mereka belum diwajibkan melakukan perintah salat. Usia diperintahkan untuk salat adalah 7 tahun, tidak serta merta anak-anak bisa melakukan perintah salat ini tanpa pembiasaaan sejak usia dini, yaitu pembiasaan diumur 7 tahun ke bawah. Adapun hasil penggalian pendapat fitur tambahan pada area salat disajikan pada Tabel 2.

Harapan orang tua, area ibadah anak jika memungkinkan dipisahkan dengan area salat utama. Pada area ini didesain secara spesifik untuk anak, seperti ruangan dengan karpet warnawarni yang anti slip dengan hiasan dinding poster tata cara salat anak, doa-doa dan adab di Masjid. Area ibadah anak ini dilengkapi dengan perlengkapan ibadah khusus anak dan kebutuhan anak yang lain seperti air minum galon. Menurut informan area ibadah ini tentunya perlu pendampingan oleh orang dewasa. Pendampingan bisa dilakukan oleh orang tua atau volunteer.

Tabel 2. Fitur tambahan pada area salat menurut pendapat informan berdasarkan urutan

\begin{tabular}{cl}
\hline No & \multicolumn{1}{c}{ Fitur Tambahan } \\
\hline 1 & Area ibadah anak \\
2 & $\begin{array}{l}\text { Gambar tata cara ibadah, doa-doa dan adab } \\
\text { anak di masjid }\end{array}$ \\
3 & Rak perlengkapan ibadah anak \\
4 & Karpet anti slip \\
5 & Air galon \\
\hline
\end{tabular}

Para orang tua sangat ingin melatih dan melakukan pembiasaaan ke anak sejak dini ke Masjid akan tetapi masih terkendala dengan masjid yang kurang ramah anak dan arah pengambilan keputusan yang belum pro ke anak. Sehingga para orang tua merasakan ketidaknyamanan dan ketidakleluasaan saat membawa anak, mereka masih khawatir ada jamaah yang menegur dan merasa terganggu dengan kehadiran anak. Begitupun sebaliknya keseganan jamaah menegur anak yang belum terbiasa dengan adab di masjid, sehingga hal ini menjadi rawan konflik.

- Fasilitas

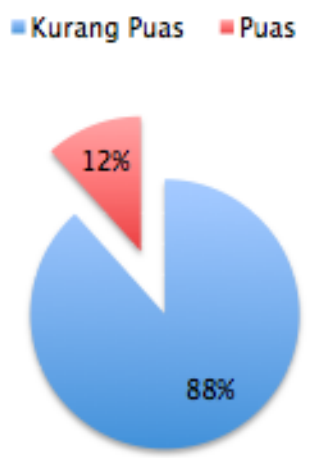

\section{Gambar 11. Pendapat informan terhadap ketersediaan fasilitas anak di masjid}

Hampir semua informan mengatakan kurang puas terhadap fasilitas anak di masjid, hanya sedikit informan mengatakan puas karena masjid saat ini sudah dijadikan pusat pendidkan Al- 
Qur'an. Informan yang kurang puas ini mengatakan bahwa fasilitas anak ada akan tetapi masih kurang dan tidak memperhatikan kemanan anak, pendapat lain mengatakan bahwa jarang menemukan fasilitas anak yang umur 5 tahun ke bawah karena yang diwadahi adalah pendidikan baca tulis alqur'an saja. Ada juga informan yang berpendapat bahwa tidak pernah menemukan fasilitas khusus untuk anak kecuali teras masjid yang selalu dijadikan anak-anak untuk bermain.

Pendapat orang tua menunjukkan bahwa masjid saat ini sudah menjadi Taman Pendidikan Al-Qur'an walaupun kurang dilengkapi dengan sarana dan prasarana khusus anak dalam belajar. Aktivitas belajar Al-Qur'an ini masih dilakukan di area salat utama atau memanfaatkan teras masjid. Sedangkan perpustakaan anak belum ditemui sama sekali di masjid manapun informan berkunjung.

Besarnya persentase informan yang menyatakan kurang puas dengan fasilitas anak di Masjid, ini menandakan bahwa ada nya harapan besar agar masjid-masjid di Makassar menyediakan dan meningkatkan fasilitas khusus anak pada masjid terutama fasilitas rekreasi untuk anak karena saat ini masjid-masjid pada umumnya sudah menjadi pusat pendidikan Al-Qur'an untuk anak.

Agar masjid menjadi pusat pembangunan masyarakat muslim maka harus mewadahi semua usia, bukan hanya untuk orang dewasa saja akan tetapi termasuk anak-anak. Menurut Utaberta [5] bahwa ada dua fasilitas anak yang ada pada masjid yaitu fasilitas pendidikan berbasis islam dan fasilitas rekreasi anak. Adapun fasilitas pendidikan seperti Taman Pendidikan Al-Qur'an dan perpustakaan anak. Sedangkan fasilitas rekreasi yaitu sarana bermain anak (perosotan, ayunan dll) serta taman.

Berdasarkan hasil penelitian didapatkan bahwa semua informan menyetujui adanya fasilitas pendidikan dan fasilitas rekreasi anak di Masjid. Kedua fasilitas ini dianggap sangat penting untuk diadakan di masjid. Hal ini menunjukkan bahwa proses belajar, bernalar dan bermain adalah tidak bisa dipisahkan.
= Fasilitas pendidikan $=$ Fasilitas rekreasi =Keduanya

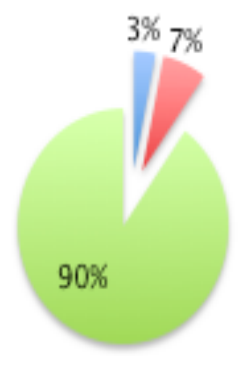

Gambar 12. Pendapat informan terhadap fasilitas pendidikan dan fasilitas rekreasi anak di masjid

Adapun penggalian pendapatterhadap fasilitas tambahan selain fasilitas pendidikan berbasis islam dan fasilitas rekreasi dapat dilihat pada tabel berikut:

Tabel 3. Fasilitas tambahan menurut pendapat informan berdasarkan urutan

\begin{tabular}{cl}
\hline No & \multicolumn{1}{c}{ Fasilitas Tambahan } \\
\hline 1 & Perpustakaan anak \\
2 & Fasilitas olahraga \\
3 & Taman edukasi \\
4 & Tempat wudhu/toilet anak \\
5 & Ruang laktasi \\
6 & Teras lapang \\
\hline
\end{tabular}

Fasilitas tambahan di atas disajikan berdasarkan urutan jumlah terbanyak, perpustakaan merupakan pendapat terbanyak. Selain perpustakaan anak disusul pendapat fasilitas olahraga, taman edukasi, tempat wudhu/toilet anak serta ruang laktasi. Sedangkan teras yang lapang merupakan hal yang tidak menjadi prioritas informan untuk diadakan.

Adapun penggalian pendapat terhadap anak terkait lingkungan masjid sebagai berikut :

"Saya ke masjid salat, kalau sudah salat langsung pulang tidak main, tapi itu kakak-kakak kalau sudah salat langsung tahambur, lari-lari di masjid. Saya harus pulang ke rumah karena mau makan". (Aisyah 4 tahun).

Aisyah anak usia 4 tahun ke masjid bersama abinya, akan tetapi tidak diberi kebebasan untuk berada di Masjid setelah aktivitas salat karena segera dibawa pulang ke rumah. Orang tuanya mendidik Aisyah dengan sangat hati-hati menjaga 
lingkungan anaknya. Anak-anak tidak pernah salah dalam meniru, ketika melihat anak yang lain berlari ke sana kemari setelah salat, maka anak yang lain pun semakin ramai melakukan hal yang sama walaupun awalnya mereka tenang karena sebelum ke Masjid orang tua sudah membekali dengan adab-adab ketika berada di Masjid. Anak usia 4 tahun belum dikenai kewajiban melakukan perintah salat sehingga di Masjid tidak perlu berlama-lama jika sudah mengganggu jamaah lain, setelah salat fardu, jamaah masih membutuhkan suasana yang tenang agar bisa khusyu' berdzikir dan salat sunnah.

Penggalian pendapat juga dilakukan pada anak yang bernama Opick yang berumur 6 tahun, respon awal adalah melihat masjid sebagai tempat salat dan mengaji saja. Selain aktivitas salat dan mengaji tidak diperbolehkan. "Masjid untuk salat dan mengaji, tidak boleh main-main" (Opick, 6 Tahun).

Sedangkan penggalian pendapat pada Aira yang berumur 9 tahun sepakat jika di Masjid ada area salat khusus anak dan sarana bermain anak. "Kalau ada area salat anak, saya mau salat di situ. Tidak salat di area salat ibu-ibu." (Aira, 9 tahun).

Anak-anak membutuhkan area yang spesifik dalam melakukan aktivitas, selain area serba guna pada area salat utama. Begitupun dengan Opick yang awalnya bersikeras bahwa masjid tempat salat dan ngaji bukan tempat main, semakin digali pendapatnya bahwa tempat main di luar bukan di dalam ruang salat, aira dan opick sepakat bahwa kalau begitu boleh bermain di Masjid dan saya suka.

"Saya mau main perosotan, ayunan di Masjid. Kalu salat mau di tempat anak-anak, tidak ikut di tempat Abi' lagi." (Opick, 6 tahun).

\subsection{Analisis Fitur dan Fasilitas Masjid yang} Mampu Merawat dan Menumbuhkan Fitrah Keimanan Anak

- Merawat dan Menumbuhkan Fitrah Keimanan Anak Melalui Interaksi Masjid

Bagaimana merawat dan menumbuhkan fitrah keimanan anak tidak terlepas dari pendidikan. Pendidikan adalah katalisator dari tumbuh nya fitrah anak secara utuh. Pendidikanlah yang menumbuhkan semua potensi fitrah menuju misi penciptaan manusia baik misi secara individu maupun misi secara komunitas.

Menurut Syantut [8] dalam bukunya merawat fitrah anak laki-laki disebutkan bahwa ada 4 pilar pendidikan anak yaitu:

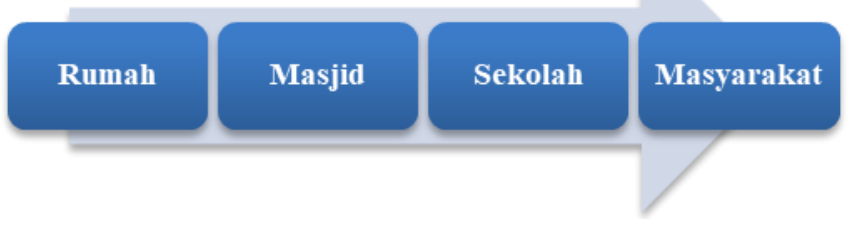

Gambar 13. 4 (empat) pilar pendidikan dasar anak [8]

Rumah adalah tempat pertama yang menerima kehadiran anak di dunia ini, di rumahlah tempat anak menghabiskan waktu terbanyak dan dirumahlah mereka memilki panutan yaitu Ayah dan Bundanya. Olehnya itu rumahlah yang menjadi pilar utama, pilar terpenting, dan pilar yang paling berpengaruh pada peradaban.

Anak sejak lahir ia terlahir dengan fitrah, rumahlah yang menentukan apakah akan merawat dan menumbuhkan fitrah nya atau sebaliknya memudarkannya atau bahkan merusaknya. Di mana tempat terbaik merawat dan menumbuhkan fitrah keimanan anak setelah rumah? Hal ini bergantung pada di mana kesadaran beragama muncul, apakah dari masjid atau dari rumah. Di beberapa wilayah kesadaran agama muncul dari sekolah atau kampus-kampus. Akan tetapi saat ini, jika membandingkan kedua nya masjid lebih mudah di dapatkan keberadaannya dibanding dengan keberadaan sekolah yang berbasis islam.

Sadar atau tidak, masjid dan sekolah dijadikan sebagai media penyebaran paham sekuler untuk menghancurkan generasi muslim. Hal ini terlihat dari pergeseran fungsi masjid sebagaimana yang telah dipaparkan pada latar belakang bahwa masjid cenderung hanya sebagai tempat salat 5 waktu. Di luar waktu salat masjid sepi dengan aktivitas. Kita harus menjadikan masjid sebagai tempat pendidikan kedua setelah rumah dan sebelum mengenalkan anak dengan sekolah.

Bagaimana cara anak belajar? Montessori dalam Scott [9] membagi ke dalam 4 tahap pengembangan : 
- Umur 0-6, pikiran penyerap; menyerap dari lingkungan, budaya dan bahasa. Umur 6-12, pikiran yang beralasan; pemikiran dan imajinasi abstrak.

- Umur 12-18 pikiran humanis; bertanya tentang masyarakat dan keseluruhan

- Umur 18-24 pikiran spesialis; prihatin dengan peran mereka dalam keseluruhan

Di usia 0-6 tahun merupakan masa kanakkanak awal (pra- tamyiz) ibarat sebuah bangunan ini adalah masa penanaman pondasi. Pondasi yang kuat akan mampu menahan tantangan yang besar di masa-masa yang akan datang. Menurut Risman [10] besarnya tantangan orang tua di era digital ini, jika tidak ada susah payah di masa kanakkanak awal maka orang tua akan disusahi oleh anaknya ketika dewasa nanti.

Elitazari dalam Scott [9] usia 0-6 tahun ini anak-anak belajar dengan menyerap pengalaman dari lingkungan sekitarnya melalui semua inderanya kemudian diolah melalui otak. Akan tetapi di usia 0-3 tahun anak-anak menyerap namun tidak disadarinya, sedangkan usia 3-6 tahun anak-anak menyerap lingkungannya secara sadar dan memiliki tujuan.

Oleh karena itu pentingnya menjaga indera anak di fase kanak-kanak awal ini. Pada fase kanak-kanak awal perlihatkan, perdengarkan halhal yang baik, hal-hal yang indah, hal-hal yang menyenangkan. Penuhi pengalamannya dengan imaji-imaji positif bukan sebaliknya. Golden age fitrah keimanan adalah pada masa anak-anak, sehingga tempat terbaiknya setelah rumah adalah masjid.

- Fitur Ruang Salat Ramah Anak

Berdasarkan hasil survey tujuan utama orang tua membawa anak ke masjid adalah mengenalkan dan belajar salat 5 waktu sejak dini agar kelak hatinya terikat dan mencintai masjid.

Area salat merupakan sumber konflik utama kehadiran anak-anak di masjid, terjadi konflik kepentingan antara orang dewasa yang ingin beribadah secara khusyu' dan anak-anak yang ingin belajar beribadah sejak usia dini.

Orang tua sebagai pendidik pertama dan utama dalam keluarga yang bertanggung jawab terhadap pendidikan anaknya, seringkali dilema ketika hadir di masjid dan membawa anak. Dilema antara keinginan mengenalkan masjid setelah lingkungan rumah sejak usia dini atau menunggu kondisi ideal anak dan lingkungan masjid menerima kehadiran anak di Masjid.

Bagaimana agar konflik ini tidak terjadi lagi? Orang dewasa tetap bisa beribadah secara khusyu' dan anak-anak tidak dihalangi tujuan utama orang tuanya membawanya ke masjid.

Keberadaan anak di masjid bukan inti masalah nya, yang bermasalah adalah perilaku anak, berteriak sehingga menimbulkan suara bising, berlari ke sana ke mari di depan saf salat dan berbagai aktivitas anak yang menimbulkan ketidaknyamanan jamaah.

Aktivitas ibadah adalah salah satu aktivitas yang sifatnya privat, aktivitas yang sifatnya privat butuh ruang yang tidak bising. Sehingga sebaiknya ruang salat dibuat ruang khusus. Ruang khusus ibadah buat anak, terpisah dari ruang slat utama namun tetap terkoneksi dengan ruang salat utama.

Apa yang membuat ruang salat anak harus berbeda dengan ruang salat utama? Menurut Montessori dalam Scott [8] anak-anak membutuhkan ruang khusus yang tidak terlalu besar dan tidak terlalu kecil. Hal ini berkaitan dengan tingkat stress pada anak, ada korelasi antara tingkat stress anak dengan ruangan yang memilki fungsi sebaguna. Ruang yang terlalu besar dan digunakan untuk beberapa kegiatan dapat menyebabkan kebisingan dan kebingungan, namun ruangan yang terlalu kecil dapat menimbulkan tingkat stres dan kecemasan yang lebih tinggi. Moore dalam Scott [9] pada buku yang berjudul Architecture For Children menyebutkan bahwa luas yang ideal adalah 42-50 kaki persegi per anak.

Ruang salat khusus anak di desain dengan pendekatan anak, dilengkapi dengan perlengkapan ibadah khusus anak seperti mukena anak, sajadah anak, peci anak, Al-Qur'an anak dll. Agar anakanak tetap aman, nyaman dan sehat maka elemenelemen interior ruang salat anak harus disesuaikan dengan kebutuhan anak. 
Tabel 4. Deskripsi elemen desain pada ruang salat anak

\begin{tabular}{|c|c|c|}
\hline No. & $\begin{array}{l}\text { Elemen } \\
\text { Desain }\end{array}$ & Deskripsi \\
\hline 1 & Lantai & $\begin{array}{l}\text { Material lunak seperti karpet tebal } \\
\text { dan puzzle mat }\end{array}$ \\
\hline 2 & Dinding & $\begin{array}{l}\text { GRC panel sebagai peredam bising } \\
\text { pada dinding non struktur, cat } \\
\text { dinding kidsproof technology, } \\
\text { transparan, dinding sebagai media } \\
\text { belajar (sticker tata cara salat, adab } \\
\text { di masjid dll) }\end{array}$ \\
\hline 3 & $\begin{array}{l}\text { Langit- } \\
\text { langit }\end{array}$ & $\begin{array}{l}\text { Plafond akustik dengan } \\
\text { menggunakan gypsum board dan } \\
\text { atraktif. } \\
\text { Ketinggian plafond } 2,5 \text { meter }\end{array}$ \\
\hline 4 & Jendela & Sliding wall, transparan \\
\hline 5 & $\begin{array}{l}\text { Perabot } \\
\text { ruang }\end{array}$ & $\begin{array}{l}\text { Rak perlengkapan ibadah anak } \\
\text { (menyesuaikan proporsi tubuh anak) }\end{array}$ \\
\hline
\end{tabular}

Jika fitur pada area salat menerapkan elemenelemen desain berdasarkan deskripsi di atas maka anak-anak akan merasa aman, nyaman dan sehat selama beraktivitas di Masjid khususnya di area salat. Desain pada area salat anak harus merespon perilaku anak yang menyukai tantangan, tidak suka duduk teratur seperti orang dewasa. Mereka tidak hanya berjalan, tetapi juga melompat, merangkak, dan berlari. Kesemua penerapan elemen desain di atas sebagai upaya menjaga kenyamanan, keselamatan dan keamanan anak saat beraktivitas.

- Fasilitas Anak di Masjid Berdasarkan Fitrah Perkembangan Anak

- Usia 0-2 Tahun

Di usia 0-6 bulan kebutuhan pokok anak adalah Air Susu Ibu (ASI). ASI yang didapatkan dari ibu kandungnya. Menurut Rebel dalam Syantut [8] disebutkan bahwa dalam diri seorang anak usia dini, terdapat kebutuhan naluri untuk selalu dekat dengan ibunya. Jika seorang ibu dapat memberikan kebutuhan tersebut, ia telah membantu anaknya berkembang secara optimal.

Sejak lahir anak sudah membawa pokok kebaikan (innate goodness) untuk menjalani peran spesifiknya menuju maksud penciptaan manusia yaitu untuk beribadah sebagai Hamba Allah dan sebagai Khalifah di muka bumi ini.

Ini tahap penguatan fitrah keimanan dengan memberikan ASI secara eksklusif, menghadirkan hati, perhatian, sentuhan, pandangan dan sebagainya ketika menyusui. Inilah tahap penguatan awal Tauhid Rubbubiyatullah.

Tauhid rubbubiyatullah adalah keyakinan bahwa tidak ada pencipta kecuali Allah, dan Allah lah satu-satunya yang mencipta, mengatur, menghidupkan, mematikan, memberikan rezeki kepada makhluk-makhluk yang ada di langit dan di bumi.

Jadi, tatkala seseorang mengaku beriman kepada Allah, berarti dia harus meyakini bahwa hanya Allah sajalah satu-satunya yang menciptakan, mengatur, dan memberikan rezeki di alam ini.

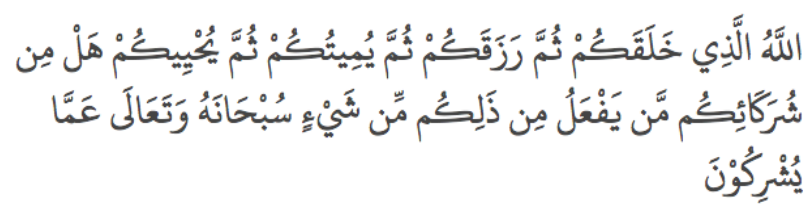

Artinya :

Allahlah yang menciptakan kamu, kemudian memberimu rezki, kemudian mematikanmu, kemudian menghidupkanmu (kembali). Adakah di antara yang kamu sekutukan dengan Allah itu yang dapat berbuat sesuatu dari yang demikian itu? Maha Sucilah Dia dan Maha Tinggi dari apa yang mereka persekutukan. (QS Ar-Rum [30]: 40)

Berdasarkan hasil observasi lebih dari separuh informan mengunjungi masjid setiap dan lebih dari separuh informan juga berjenis kelamin perempuan, dan hampir separuhnya setiap ke Masjid membawa anak. Ini menandakan bahwa frekuensi Ibu berada di Masjid cukup tinggi. Mereka sekedar singgah salat, ataupun tujuan lain seperti kegiatan pengajian. Jika durasi pengajian rata-rata 2 jam, maka ruang laktasi pada masjid merupakan hal yang penting untuk diadakan.

- Usia 3-6 Tahun

Pada usia 3-6 tahun meruapakan tahap merawat fitrah keimanan dengan membangun imaji-imaji keindahan tentang Allah, tentang Rasulullah SAW, tentang Islam dan kebaikan lainnya sehingga melahirkan kesan dan cinta yang 
mendalam. Cinta sebelum Islam, Iman sebelum Amal.

Adanya larangan merusak imaji-imaji anak pada usia 3-6 tahun tentang indahnya al-Haq. Para ulama meminta untuk menunda menceritakan tentang neraka, perang akhir zaman, Dajjal, qiyamat dan seterusnya, sampai benar benar fitrahnya kuat untuk menerima informasi itu , yaitu usia anak 7 tahun ke atas. Dilarang mendidik adab dengan memaksa, menyakitkan hatinya, dan seterusnya, agar tidak membenci adab, namun selalu berupaya dengan adab yang berkesan indah.

Pada tahap ini sepenuhnya tentang cinta, namun tidak memperturutkan hal yang tidak baik. Ceritakanlah hal hal indah yang membuat ananda sangat tergugah, berkesan mendalam dan antusias pada kebenaran.

Suasanakanlah keshalihan dalam setiap momen dan kesempatan tanpa terasa dan formal. Ini tahap emas untuk mengenalkan Allah, Rasulullah SAW dan kebaikan kebaikan Islam. Anak sedang pada puncak imaji dan abstraksinya, alam bawah sadarnya masih terbuka lebar, maka mengenalkan apapun ttg kebaikan apalagi dengan cara berkesan akan masuk ke dalam alam bawah sadarnya dan menguatkan fitrahnya.

Penting mengkontekskan semua peristiwa baik dengan Allah dalam setiap kesempatan. Teladankan kebaikan tanpa pasang target untuk segera diikuti.

Hindari semua bentuk formal dan penerapan disiplin yang membuatnya jadi membenci kebaikan itu sendiri. Ingat bahwa sholat baru diperintah saat usia 7 tahun, jadi di bawah 7 tahun sholat diimajikan indah bukan dipaksa tertib gerakan, tertib bacaan, tertib waktu. Misalnya penting setiap azan berkumandang, wajah bunda menjadi sumringah dan tersenyum seindah mungkin, bahkan memeluk dan mengucapkan kata kata indah di telinga ananda. Dahulukan amar ma'ruf daripada nahi munkar. Misalnya jika ananda naik ke atas meja, katakan saja "nak meja untuk makan, kaki untuk ke masjid atau ke taman" daripada panik dan menyebut keburukan.

Pada usia 3-6 tahun masih dalam fase pra latih menuju pelaksanaan perintah salat. Pada tahap ini masih merupakan konsepsi pundamental merawat fitrah anak melalui kecintaan keluarga. Cara belajar anak pada usia ini anak menyerap dari lingkungan secara sadar dan punya tujuan. Fitrah belajar anak melalui keteladanan dan atmosfir kesalihan, sedangkan interaksi terbaiknya adalah kitabullah.

Pada fase ini anak sudah antusias mengenal dan menyebut nama Allah di usia 3 tahun, sehingga kelak di usia 7 tahun, pada saat diperintahkan salat anak menerimanya dengan suka cita. Pada usia 3-6 tahun adalah masa emas bagi mendidik fitrah keimanan, dengan menguatkan konsep Allah sbg Robb, melalui imaji-imaji indah yang melahirkan kecintaan kpd Allah, Rasulullah SAW, Islam.

Perkembangan fisik (motorik) anak pada usia 3-6 tahun senang meniru gerakan, mampu melompat, melempar, menari, naik turun tangga dengan berpegangan atau memanjat, mengendarai sepeda, senang bermain air dan pasir, dan aktivitas ini dilakukan secara terkoordinasi.

Sedangkan secara kognitif kemampuan anak di umur 3-6 tahun sudah mampu melakukan social play, mampu bekerjasama, berbagi, bereksplorasi serta mampu mengikuti arahan bermain.

Aktivitas fisik di atas sangat menggangu jika dilakukan di area salat utama, dengan melihat kemampuan kognitif dan kemampuan sosial anak di usia ini maka perlu diwadahi fasilitas rekreasi seperti area permainan yang sesuai seperti lapangan kecil dengan ayunan, perosotan, jungkat-jungkit, lompat jauh, lapangan pasir dan rumput dan lain sebagainya.

Pada usia 3-6 tahun ini anak-anak tidak bisa dipaksa tenang mengikuti gerakan salat, tepat waktu dan tepat bacaan. Olehnya pada usia ini masih dalam pendampingan penuh orang tua sehingga fasilitas rekreasi anak berdampingan dengan area salat utama di mana orang tua beraktivitas paling banyak.

- Usia Anak 7-10 Tahun

Ini adalah tahap menumbuhkan dan menyadarkan tauhid mulkiyatullah. Tauhid Pada tahap ini anak sedang sangat kritis (fitrah belajar dan bernalar pada puncaknya), mereka juga mulai bergeser dari ego sentris ke sosio sentris, mereka mulai memahami adanya keteraturan di alam dan 
di kehidupan. Inilah tahap yang tepat untuk menumbuhkan dan menyadarkan bahwa Allahlah Sang Maha Pengatur, Sang Maha Pembuat Hukum, Zat Yang harus ditaaati.

Fitrah keimanannya ditumbuhkan dengan membaca alam dan mentadaburi keteraturan ciptaan Allah di alam semesta. Fitrah keimanan tumbuh baik dengan menginteraksikannya pada kenyataan adanya keteraturan yang indah dan sempurna alam semesta. Keimanannnya mulai berbunga menjadi keinginan kuat memahami keteraturan itu dan mencintai Sang Maha Pengaturnya. Keimanan tidak bisa lagi lewat kisah kisah menjelang tidur, namun harus dialami langsung dengan interaksi di alam.

Fitrah Keimanan yang tumbuh paripurna akan berujung kepada peran peradaban berupa gairah dan antusias menyeru kepada Tauhidullah. Inilah adab tertinggi kepada Allah sebagaimana yang ditugaskan kepada para Nabiyullah Alaihimusalaam sepanjang sejarah.

Pada usia 7-10 tahun kecepatan dan kehalusan motoriknya meningkat sehingga sangat aktif dan energik, semakin meningkat kesenangannya dengan aktivitas fisik yang sifatnya kejar-kejaran, mereka membutuhkan ruang gerak aman tanpa pengawasan akan tetapi menantang, sehingga fasilitas yang cocok pada usia ini adalah fasilitas olahraga.

Tabel 5. Fasilitas anak di masjid berdasarkan fitrah perkembangan anak

\begin{tabular}{|c|c|c|}
\hline $\begin{array}{l}\text { Usia } \\
\text { Anak }\end{array}$ & Ruang & Fasilitas \\
\hline $0-2$ & Ruang laktasi & Fasilitas Pendukung \\
\hline \multirow[t]{4}{*}{$3-6$} & $\begin{array}{c}\text { Taman Pendidikan } \\
\text { Al-Qur'an }\end{array}$ & Fasilitas Pendidikan \\
\hline & Perpustakaan anak & Fasilitas Pendidikan \\
\hline & Sarana bermain anak & Fasilitas Rekreasi \\
\hline & Tempat wudhu anak & Fasilitas Pendukung \\
\hline $7-10$ & & Fasllitas olahraga \\
\hline
\end{tabular}

\section{Kesimpulan}

Beberapa hal yang dapat disimpulkan dari penelitian ini antara lain:

- Fitur dan fasilitas anak pada masjid-masjid di Makassar belum memuaskan, perlu ditingkatkan. besarnya harapan orang tua agar masjid-masjid lebih ramah anak dan meningkatkan fasilitas anak di Masjid.

- Fitur dan fasilitas masjid yang berbasis potensi fitrah anak akan menjadi faktor penarik anak-anak agar nyaman dan betah berada di Masjid. Dengan anak-anak betah dan nyaman berada di Masjid mencegah mereka berkunjung ke tempat-tempat lain yang memberikan kenyamanan namun berbahaya bagi masa depan mereka. Besarnya tantangan orang tua dalam mendidik anak di era digital ini, akan menjadikan support yang kuat terhadap orang tua dalam mendidik anaknya ketika masjid menjadi rumah kedua bagi anak-anak. Masjid yang menjadi rumah kedua bagi anak-anak, kelak anak-anak terpaut hatinya dengan masjid, sehingga anak-anak sangat siap dengan segala kewajiban yang melekat pada dirinya di usia baliqh.

\section{Ucapan Terimakasih}

Penelitian ini dapat dilakukan berkat dukungan dari banyak pihak. Ucapan terimakasih yang tak terhingga kepada informan dalam penelitian ini yaitu komunitas HEbAT, IIP, dan ICATT.

\section{Referensi}

[1] F. A. Nugroho, "Realitas Anak Jalanan Di Kota Layak Anak Tahun 2014(Studi Kasus Anak Jalanan di Kota Surakarta) “, Universitas Sebelas Maret, April 2014.

[2] M. I. A. Hamudi, "Upaya Mewujudkan Kota Layak Anak di Surakarta dan di Makassar", Jurnal Bina Praja, Vol.7, No.2, April 2015, pp.149-160.

[3] A. Suratkom, dkk, "Woman Friendly Mosque, Features and Facilities: A Case Study on Masjid Sultan Ibrahim, Universiti Tun Hussein On Malaysia”, International Conference on Architecture and Civil Engineering, 2017.

[4] T. B. Ngaderi, diakses melalui https://www.kompasiana.com/m.trimanto/5959dcb6c22 2bde30a27bc6d/masjid-layak-anak?page=all, pada 8 April 2019.

[5] N. Utaberta, A. Nayeem. "Masjid, The Spiritual and Physical Hub for Community Development”, UPM: WARIS Research Group, 2016.

[6] Sugiono, "Metode Penelitian Pendidikan Pendekatan Kuantitatif, kualitatif, dan R\&D”. Bandung: Alfabeta, 2010.

[7] Imriyanti, "Mosque Architecture as A Sustainable Building In Urban (Case Study: Al Markas Al Islamic Mosque Makassar)”, Journal of Islamic Architecture, Volume 2 Issue, 2013. 
[8] K. Syantut, "Merawat Fitrah Anak Perempuan", Tejemahan oleh Iman Matin, Cet. Ke-1, Jakarta Selatan: Maskana Media, 2019.

[9] S. Scott, "Architecture for children", Acer Press:
Australia, 2010

[10]E. Risman, "Peran Keluarga Dalam Membangun Insan Berkarakter", Auditorium BKKBN, pptx, 27 April, 2015. 